\title{
Derivatization of Enolic OH of Piroxicam: a Comparative Study on Esters and Sulfonates
}

\author{
J. Jayaselli, J. Manila Sagar Cheemala, Geetha Rani D. P. and Sarbani Pal** \\ Department of Chemistry, MNR Post Graduate College, Kukatpally, Hyderabad, India
}

\begin{abstract}
Vários ésteres e sulfonatos derivados da piroxicam foram preparados por acilação e sulfonação da hidroxila fenólica da piroxicam. Todos os compostos foram avaliados quanto à estabilidade química e às propriedades de inibição da ciclooxigenase. Os dados sugeriram que os ésteres poderiam ser o ponto de partida para o desenvolvimento de fármacos em potencial. Os sulfonatos derivados, preparados pela primeira vez, apresentaram estabilidade. Entre eles, um demonstrou uma moderada seletividade de inibição da COX-2 sobre a COX-1 e teria menor efeito colateral para o sistema gastrintestinal que a piroxicam devido ao grupo $\mathrm{OH}$ enólico mascarado. Um mecanismo plausível para o processo de acilação e sulfonação foi proposto, envolvendo a participação da porção da piridina presente na piroxicam. A estrutura molecular de um dos ésteres foi estabelecida, pela primeira vez, por meio de análise cristalográfica dos dados de raio-X de difração de pó.
\end{abstract}

A number of ester and sulfonate derivatives of piroxicam were prepared via acylation/ sulfonation of the enolic $\mathrm{OH}$ of piroxicam. All the compounds were evaluated for their chemical stability and cyclooxygenase inhibiting properties. Data suggested that esters could be useful for the development of potential prodrugs. The sulfonate derivatives prepared for the first time were found to be stable. One of them showed a moderately selective COX-2 inhibition over COX-1 and would have lower gastrointestinal side effects than piroxicam due to the masked enolic $\mathrm{OH}$ group. A plausible mechanism for the acylation/sulfonation process has been proposed that involves participation of the pyridine moiety of piroxicam. Molecular structure of one of the ester was established for the first time by the crystal structure analysis from X-ray powder data.

Keywords: piroxicam, esters, sulfonates, cyclooxygenase

\section{Introduction}

Piroxicam (1, 1,2-benzothiazine-3-carboxamide-4hydroxy-2-methyl- $N$-(2-pyridyl)-1,1-dioxide, Figure 1), ${ }^{1}$ a nonsteroidal anti-inflammatory drug (NSAID) that belongs to the enol-carboxamide class, was developed prior to the discovery of cyclooxygenase-2 (COX-2, the second and inducible isoform of cyclooxygenase responsible for inflammation) on the basis of its anti-inflammatory activity and relative safety in animal models. In subsequent studies it was discovered that it possessed moderate COX-2 selectivity in compared to other COX-2 inhibitors. Several attempts were made to improve its pharmacological profile in addition to gastrointestinal side effects. For example, extensive SAR studies have been carried out in order to improve its COX-2/COX-1 selectivity profile which includes substitution at the 6- and 7-positions of the 4-oxo-1,2-benzothiazine-3-carboxamide, alteration of the

*e-mail: sarbani277@yahoo.com
$N$-methyl substituent, and amide modification. ${ }^{1}$ In another approach, the enolic $\mathrm{OH}$ group thought to be responsible for its COX-2 selectivity has been exploited as a "handle" for the preparation of various piroxicam derivatives. ${ }^{2-5}$ These derivatives are inactive against cyclooxygenase but converted to piroxicam during or after absorption, thus minimizing the potential for gastrointestinal irritation due to topical cyclooxygenase inhibition and prostaglandin depletion by the free drug. Several of these piroxicam prodrugs $^{6}$ are now marketed including ampiroxicam, an ether carbonate derivative of piroxicam., ${ }^{2,3}$

As a chemical class piroxicam offered interesting structural features due to the presence of acidic enolic $\mathrm{OH}$ that prompted medicinal chemists/pharmacologists for further studies. For example, unlike other acidic NSAIDs that possess carboxylic acid functional group piroxicam did not show any effect when tested for prostaglandin-independent inhibition of calcium transport. ${ }^{7}$ In another study it has been shown that because of the presence of enolic $\mathrm{OH}$ group piroxicam can adopt different structures depending on the $\mathrm{pH}$ 

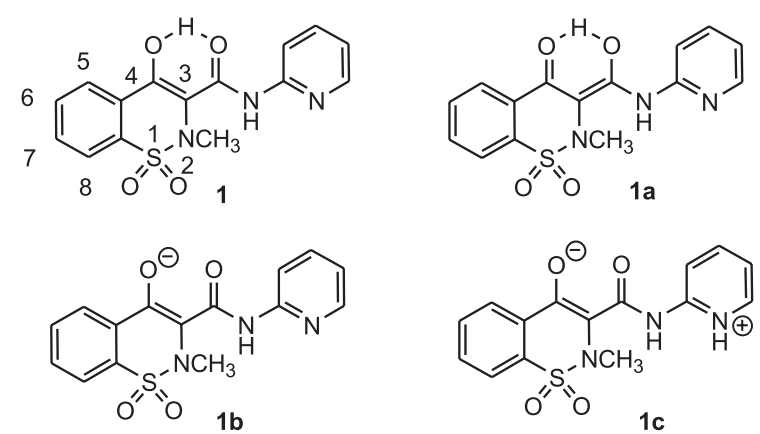

Figure 1. Piroxicam (1) and its alternative structures under various conditions.

of the medium. ${ }^{7}$ At neutral $\mathrm{pH}$, under biologically relevant conditions, the anionic structure predominates $(\mathbf{1 b}$, Figure 1). ${ }^{8}$ At the ground state it may exist in various conformations because of its ability to form inter- and intramolecular H-bonds. Upon electronic excitation of the closed enol structure (1) in nonpolar solvents, an intramolecular protontransfer reaction takes place, transforming it to the keto-type form (1a, Figure 1). ${ }^{9}$ In protic solvents, a second species called an open conformer (1c, Figure 1) is formed. ${ }^{10}$ Furthermore, piroxicam caged within cyclodextrins (CD) and micelles was studied..$^{911-13}$ At $\mathrm{pH}=4,1$ in $\mathrm{CD}$ exists as the closed conformer $\mathbf{1 b} .^{9}$ In reverse micelles containing water, the anionic species predominates in addition to the presence of open and closed conformers. ${ }^{12}$

All these studies indicate that the enolic hydroxy group plays an important role in the observed physico-chemical and pharmacological properties displayed by piroxicam. Therefore derivatization of this group via alkylation or acylation is expected to change all these properties of piroxicam. This is exemplified by the development of the ampiroxicam, an ether carbonate derivative of piroxicam, ${ }^{2,3}$ droxicam, ${ }^{4}$ (Figure 2 ) piroxicam pivalic ester or cinnoxicam (piroxicam cinnamate). ${ }^{5}$ These derivatives containing masked enolic $\mathrm{OH}$ group are stable under gastric conditions and cause lower gastrointestinal irritation. However, they are sufficiently labile toward hydrolysis to allow release of $\mathbf{1}$, preferably during or immediately after absorption from the gastrointestinal track. ${ }^{6}$ While a number of piroxicam<smiles></smiles><smiles>Cn1c(=O)c2c(=O)n(-c3ccccn3)c(=O)oc2c2ccccc21</smiles>

Figure 2. Prodrugs of piroxicam

derivatives have been explored for the development of appropriate prodrugs only limited studies have been reported on the acyl derivatives and none on sulfonyl derivatives of piroxicam. Due to our continued interest in the chemical modifications of existing cycloxygenase inhibitors we have reported the synthesis of nimesulide and naproxen derivatives recently. ${ }^{14}$ Herein we report our more recent study on derivatization of piroxicam via preparing the corresponding esters and sulfonates followed by evaluation of their chemical and pharmacological properties.

\section{Results and Discussion}

Thus when piroxicam (1) was treated with acyl chloride (2) or sulfonyl chloride (3) in the presence of triethylamine in chloroform corresponding acyl or sulfonyl derivatives (4 or 5) were isolated in good yields (Scheme 1). A number of piroxicam derivatives were prepared following this procedure and the results are summarized in Table 1. Although piroxicam can adopt different structures as shown in Figure 1, only O-acylated or O-sulfonylated products were isolated from the reaction mixture. No other significant side products arising from any or all of these alternative structures were detected. However, formation of other regioisomers can not be ruled out completely because isolation of pure product required recrystallization in all cases to remove unidentified impurities. In a typical procedure, to a stirred solution of $1(2 \mathrm{~g}, 6.0 \mathrm{mmol})$ in chloroform (42 mL) was added benzoyl chloride 2c (0.99 g, $7.0 \mathrm{mmol})$ in $\mathrm{Et}_{3} \mathrm{~N}(1.0 \mathrm{~mL}, 7.0 \mathrm{mmol})$ drop wise at $25^{\circ} \mathrm{C}$ under anhydrous condition. The resulting mixture

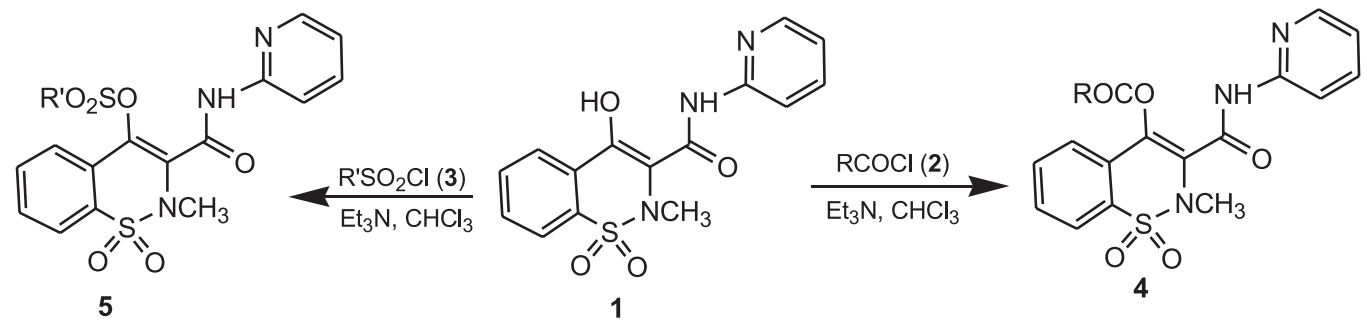

Scheme 1. Reaction of piroxicam (1) with acyl chloride (2) and sulfonyl chloride (3). 
Table 1. Synthesis of O-acylated and O-sulfonylated derivatives of piroxicam $^{a}$

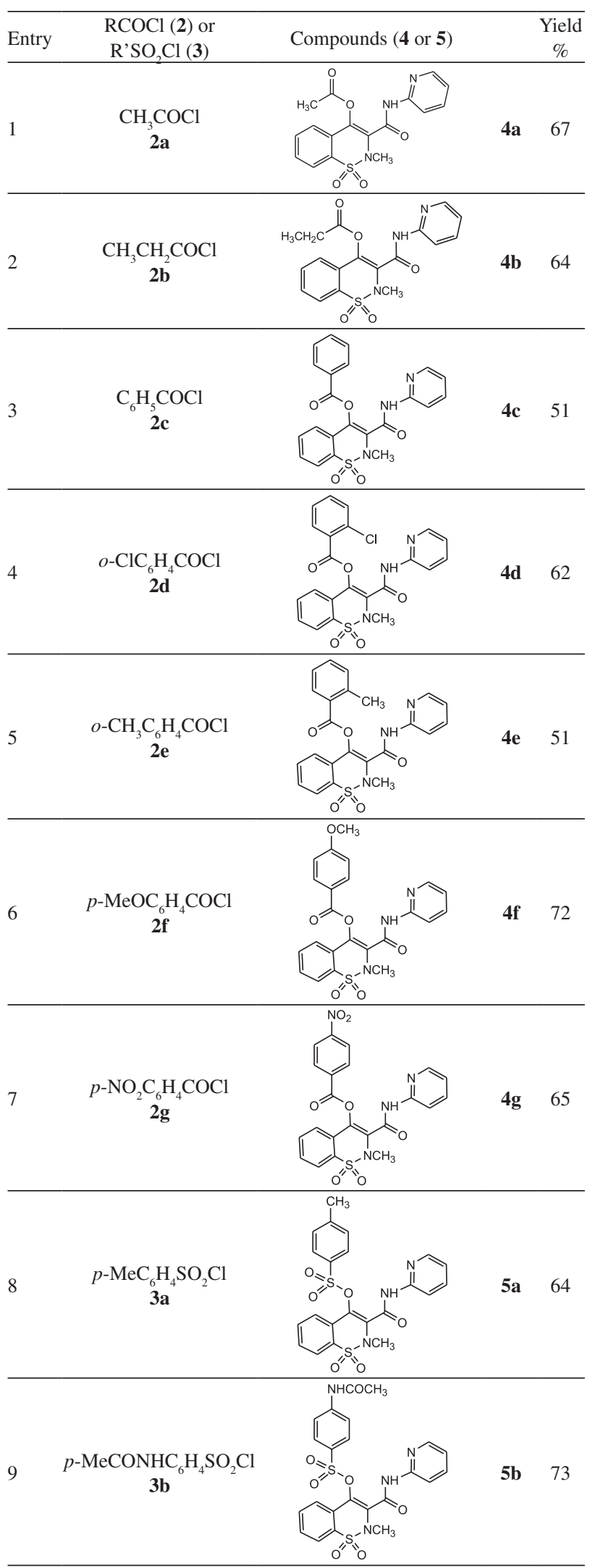

${ }^{a} \mathrm{All}$ the reactions were carried out using piroxicam (1), $\mathrm{Et}_{3} \mathrm{~N}$ (1.2 equiv) and halide 2 or 3 (1.2 equiv) in chloroform at $25^{\circ} \mathrm{C}$. was stirred at $25{ }^{\circ} \mathrm{C}$ for $6 \mathrm{~h}$. After usual work up and purification the corresponding product was isolated in 51\% yield. The acylation/sulfonation of piroxicam proceed via generation of the anion $\mathbf{1 b}$ in situ, which then participates in the reaction via enolic oxygen of the benzothiazine ring preferentially over the enolic oxygen of 3-carboximide moiety perhaps due to the higher resonance stabilizaton of the former anion (Scheme 2).

It is possible that the pyridine moiety of $\mathbf{1 b}$ generates the actual reactive species from the acyl/arylsulfonyl halide that then transfer the acyl/arylsulfonyl group to the enolic oxygen in an intramolecular fashion thereby facilitating the reaction. Pyridine is known to acylate alcohols, phenols and amines via the formation of a pyridine-acyl chloride complex. ${ }^{15}$ In order to gain experimental evidences on the role of pyridine moiety the reaction of $\mathbf{1}$ with $\mathbf{2 c}$ was carried out in the absence of triethylamine. However, this study remained inconclusive due to the isolation of an inseparable mixture of products.

All the compounds synthesized were well characterized by spectral ( ${ }^{1} \mathrm{H}$ NMR, IR and Mass) data. This was further supported by the crystal structure analysis from X-ray powder data ${ }^{16}$ of 1,2-benzothiazine-3-carboxamide-4O-(4-methoxybenzoyl)-2-methyl- $N$-(2-pyridyl)-1,1dioxide, $\mathrm{C}_{23} \mathrm{H}_{19} \mathrm{~N}_{3} \mathrm{O}_{6} \mathrm{~S}(\mathbf{( 4 f}) .{ }^{17}$ There are only few examples known involving the use of this technique for structure determination of organic compound. The molecular view of compound $\mathbf{4 f}$ with atom numbering scheme is shown in Figure 3. The compound consists of a piroxicam skeleton with a methoxybenzoyl substitution at the 4-position. The torsion angles $\mathrm{O} 3-\mathrm{C} 7-\mathrm{C} 8-\mathrm{C} 18-17.9(3)^{\circ}$, O6-C18-C8-C7 $29.3(4)^{\circ}$ and $\mathrm{H}(\mathrm{N} 2)-\mathrm{N} 2-\mathrm{C} 18-\mathrm{O} 6179.3^{\circ}$ indicate that the atom $\mathrm{O} 6$ is on the same side of molecule as atom $\mathrm{O} 3$ with respect to the $\mathrm{C} 7-\mathrm{C} 8-\mathrm{C} 18-\mathrm{N} 2$ chain, while the $\mathrm{N} 2-\mathrm{H}(\mathrm{N} 2)$ group is on the opposite side. The relative orientation of the anilide $\mathrm{H}(\mathrm{N} 2)$ and $\mathrm{O} 6$ atoms with respect to $\mathrm{O} 3$ atom is important in piroxicam related structures because the atom N2 is involved in hydrogen bonding. The molecular conformation of $\mathbf{4 f}$ is influenced by intramolecular $\mathrm{N} 2-\mathrm{H}(\mathrm{N} 2) \cdots \mathrm{N} 1$ and $\mathrm{C} 20-\mathrm{H}(\mathrm{C} 20) \cdots \mathrm{O} 6$ interactions. A further analysis of $\mathrm{X}$-ray powder diffraction data revealed that a combination of $\mathrm{N}-\mathrm{H} \cdots \mathrm{O}, \mathrm{C}-\mathrm{H} \cdots \mathrm{O}, \mathrm{C}-\mathrm{H} \cdots \pi$ (arene) hydrogen bonds, and aromatic $\pi-\pi$ stacking interactions stabilized the crystal structure of $\mathbf{4 f}$. Pairs of intermolecular $\mathrm{N}-\mathrm{H} \cdots \mathrm{O}$ and $\mathrm{C}-\mathrm{H} \cdots \mathrm{O}$ hydrogen bonds link the molecules of $\mathbf{4} \mathbf{f}$ into centrosymmetric dimers with the formation of $\mathrm{R}_{2}{ }^{2}(14)$ and $\mathrm{R}_{2}{ }^{2}(22)$ rings which are alternately joined, so generating infinite one-dimensional polymeric chains propagating along the $[-211]$ direction. The $\mathrm{C}-\mathrm{H} \cdots \pi$ (arene) hydrogen bonds interconnect the adjacent polymeric chains into two-dimensional molecular sheets parallel to the 


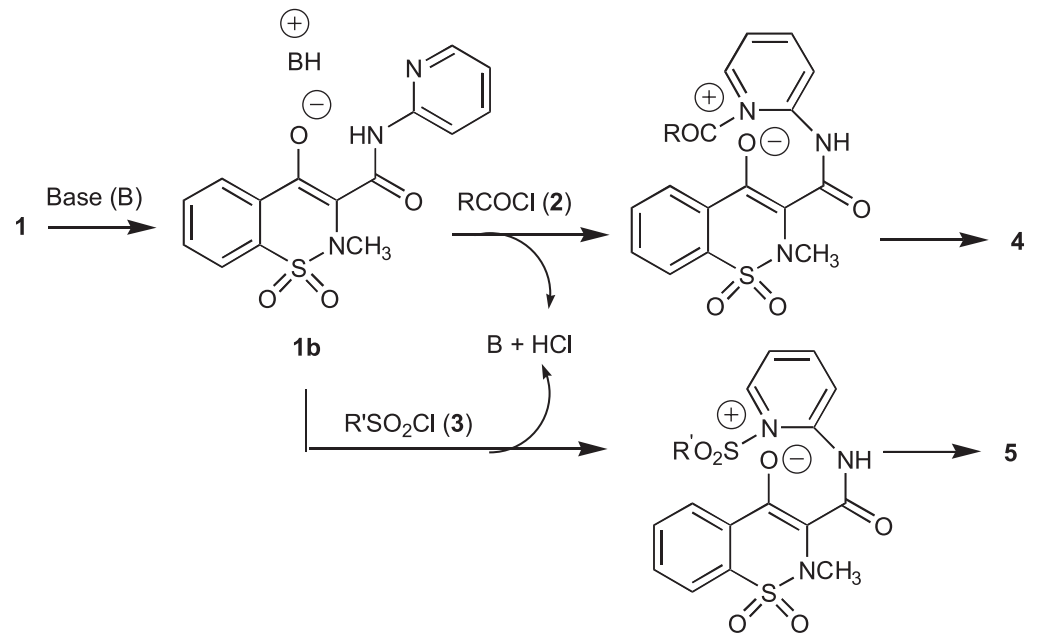

Scheme 2. Proposed reaction mechanism for acylation / sulfonation of piroxicam (1).

(102) plane, which are further linked through $\mathrm{C}-\mathrm{H} \cdots \mathrm{O}$ and $\mathrm{C}-\mathrm{H} \cdot \mathrm{N}$ N hydrogen bonds to complete the three dimensional network in $\mathbf{4 f}$.

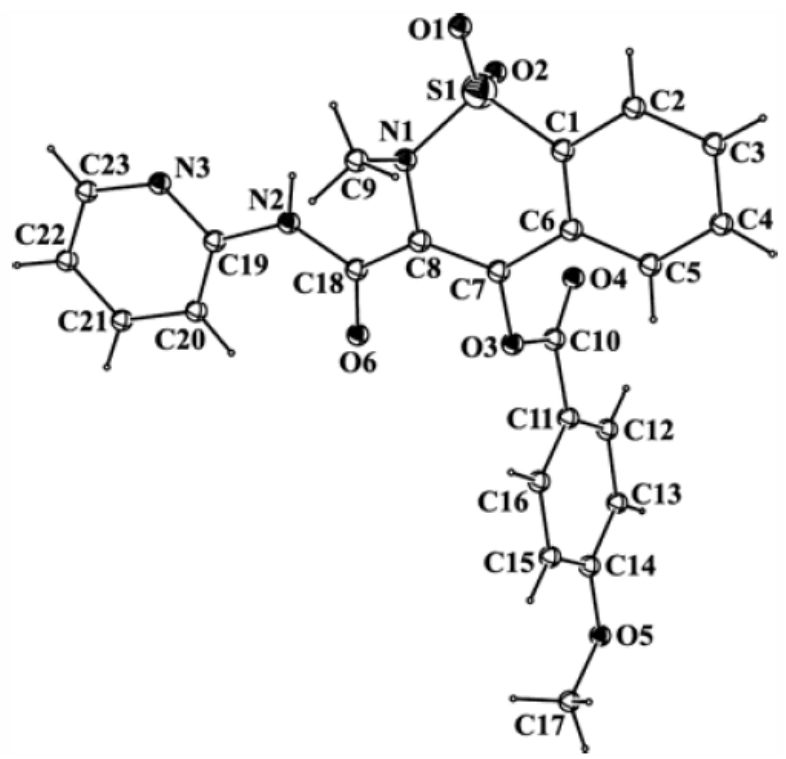

Figure 3. Molecular view of $\mathbf{4 f}$ with atom numbering scheme.

We have synthesized a number of ester and sulfonate derivatives of piroxicam with the aim of assessing their pharmacological properties. Accordingly, we focus on to gain some preliminary information about their stability under physiological condition. Thus, stability studies were carried out using all the compounds synthesized at different $\mathrm{pH}$. All the compounds were treated with $50 \mathrm{mM}$ tris buffer ( $\mathrm{pH} \mathrm{7.4)} \mathrm{and} \mathrm{percentage} \mathrm{of} \mathrm{compound} \mathrm{remained}$ after $2 \mathrm{~h}$ incubation in buffer was measured. ${ }^{18}$ Aliphatic esters $(\mathbf{4} \mathbf{a}-\mathbf{b})$ were found to be stable whereas aromatic esters $(\mathbf{4 c}-\mathbf{g})$ showed certain degree of instability as $10-20 \%$ of these esters were cleaved under the condition studied depending on the nature of substituents present. At more alkaline pH e.g. 10 (that is equivalent to the $\mathrm{pH}$ of simulated intestinal fluid) nearly all the esters (4a-g) were found to be susceptible to hydrolysis. On the other hand all the esters were stable even after $24 \mathrm{~h}$ under acidic $\mathrm{pH}$ e.g. 1.1 (equivalent to the $\mathrm{pH}$ of simulated gastric fluid). Thus, based on these observations it is expected that all these esters would show similar behavior under physiological condition. Additionally, esters are known to convert back to the active parent compound in the presence of liver microsomes. Thus, compounds 4a-g should deliver piroxicam under enzymatic condition in vivo and therefore would be more suitable for the selection of a potential prodrug candidate. Unlike esters both the sulfonate derivatives $(\mathbf{5} \mathbf{a}-\mathbf{b})$ were found to be stable across the $\mathrm{pH}$ tested and therefore might not serve as prodrug. Moreover, sulfonates are not usually substrates of human blood esterases and perhaps nor do they undergo hepatic hydrolysis.

Having assessed the stability parameters for all the compounds synthesized we next planned to evaluate their cyclooxygenase inhibitory activities. Many of these compounds were tested against cyclooxygenase enzyme in vitro ${ }^{19}$ and as expected most of the esters showed low or insignificant inhibitory effects against COX-1 and 2. For example at the concentration of $100 \mu \mathrm{mol} \mathrm{L}^{-1}$ compound $\mathbf{4 a}$ and 4 f showed $38 \%$ and $22 \%$ inhibition against COX-1 and $16 \%$ and $25 \%$ inhibition against COX-2 respectively. However, the sulfonate derivative $\mathbf{5 a}$ showed 2 folds selectivity for COX-2 over COX-1 with the \% inhibition noted as $30 \pm 2$ and $75 \pm 4$ at $100 \mu \mathrm{mol} \mathrm{L}^{-1}$ against COX-1 and COX-2 respectively. Thus, 5a can be chosen as a moderately selective new COX-2 inhibitor having masked enolic $\mathrm{OH}$ group thereby lower possibility of gastrointestinal side effects. 


\section{Conclusions}

In conclusion, we have reported synthesis of various ester and sulfonate derivatives of piroxicam via acylation/ sulfonation of its enolic $\mathrm{OH}$. A plausible mechanism for the acylation/sulfonation process has been proposed that involves participation of the pyridine moiety of piroxicam. Molecular structure of one of the ester $\mathbf{4 f}$ was established by the crystal structure analysis from X-ray powder data. The data suggested that the anilide oxygen atom and the methoxybenzoyl group lying on the same side of the molecule. A combination of $\mathrm{N}-\mathrm{H} \cdots \mathrm{O}, \mathrm{C}-\mathrm{H} \cdots \mathrm{O}, \mathrm{C}-\mathrm{H} \cdots \pi$ (arene) hydrogen bonds, and $\pi-\pi$ stacking interactions stabilized the crystal structure of $\mathbf{4 f}$. All the compounds synthesized were evaluated for their chemical stability and cyclooxygenase inhibiting properties. Data indicates that these esters have potential for the development of prodrugs. The stable sulfonate derivative $\mathbf{5 a}$ that has been reported for the first time showed a moderately selective COX-2 inhibition over COX-1. Due to the masked enolic $\mathrm{OH}$ group 5a would have lower gastrointestinal side effects than piroxicam and therefore has potential to be developed as a new anti-inflammatory agent.

\section{Experimental}

\section{General methods}

Reactions were monitored by thin layer chromatography (TLC) on silica gel plates (60 F254), visualizing with ultraviolet light or iodine spray. Flash chromatography was performed on silica gel (60-120 mesh) using distilled petroleum ether and ethyl acetate. ${ }^{1} \mathrm{H}$ NMR spectra were determined in DMSO- $d_{6}$ solution on $200 \mathrm{MHz}$ spectrometers. Proton chemical shifts $(\delta)$ are relative to tetramethylsilane (TMS, $\delta=0.00$ ) as internal standard and expressed in ppm. Spin multiplicities are given as $\mathrm{s}$ (singlet), d (doublet) and $\mathrm{m}$ (multiplet) as well as b (broad). Coupling constants $(J)$ are given in hertz. Infrared spectra were recorded on a FT- IR spectrometer. Melting points were determined by using melting point apparatus and are uncorrected. MS spectra were obtained on a JMS-D 300 spectrometer. Elemental analyses were performed on a Perkin-Elmer 240C analyzer.

Synthesis of 1,2-benzothiazine-3-carboxamide-4-O-(4methoxybenzoyl)-2-methyl-N-(2-pyridyl)-1,1-dioxide (4f)

4-methoxy benzoylchloride $(1.2 \mathrm{~g}, 0.007 \mathrm{~mol})$ in triethylamine $(1.0 \mathrm{~mL}, 0.007 \mathrm{~mol})$ was added drop wise to a solution of piroxicam $(2 \mathrm{~g}, 0.006 \mathrm{~mol})$ in chloroform
$(42 \mathrm{~mL})$ at room temperature followed by stirring for $6 \mathrm{~h}$ at $30^{\circ} \mathrm{C}$. The reaction mixture was poured into ice and extracted with chloroform $(2 \times 25 \mathrm{~mL})$. The organic layers were collected, washed with $5 \% \mathrm{NaOH}(20 \mathrm{~mL})$ solution followed by $5 \% \mathrm{HCl}(20 \mathrm{~mL})$ and then with water $(2 \times 30 \mathrm{~mL})$, dried over anhydrous $\mathrm{Na}_{2} \mathrm{SO}_{4}$, filtered and concentrated. The residue was purified by recrystallization from chloroform-EtOAc to afford microcrystalline powder of $\mathbf{4 f}$.

4-O-Acetyl-1,2-benzothiazine-3-carboxamide-2-methyl-N(2-pyridyl)-1,1-dioxide (4a)

IR $\left(\mathrm{KBr}, \mathrm{cm}^{-1}\right): 3328(\mathrm{~N}-\mathrm{H}), 1780(\mathrm{C}=\mathrm{O}), 1685(\mathrm{C}=\mathrm{O})$; ${ }^{1} \mathrm{H}$ NMR (400 MHz, $\mathrm{CDCl}_{3}$ ) $\delta 2.50(\mathrm{~s}, 3 \mathrm{H}), 3.10(\mathrm{~s}, 3 \mathrm{H})$, $7.10(\mathrm{~m}, 1 \mathrm{H}), 7.50-8.10(\mathrm{~m}, 5 \mathrm{H}), 8.40(\mathrm{~m}, 1 \mathrm{H}), 10.80$ (s, 1H); Mass (CI method): $374\left(\mathrm{M}^{+}, 100 \%\right)$; Elemental analysis: Calculated for $\mathrm{C}_{17} \mathrm{H}_{15} \mathrm{~N}_{3} \mathrm{O}_{5} \mathrm{~S}, \mathrm{C} 54.68, \mathrm{H} 4.05, \mathrm{~N}$ $11.25 \%$; found $\mathrm{C} 54.66, \mathrm{H} 4.08, \mathrm{~N} 11.35 \%$.

1,2-Benzothiazine-3-carboxamide-2-methyl-4-O-propionyl-N-(2-pyridyl)-1,1-dioxide (4b)

mp $144{ }^{\circ} \mathrm{C}$; IR $\left(\mathrm{KBr}, \mathrm{cm}^{-1}\right): 3320(\mathrm{~N}-\mathrm{H}), 1775(\mathrm{C}=\mathrm{O})$, $1683(\mathrm{C}=\mathrm{O}) ;{ }^{1} \mathrm{H}$ NMR $\left(400 \mathrm{MHz}, \mathrm{CDCl}_{3}\right) \delta 1.10(\mathrm{t}, J=$ $7.5 \mathrm{~Hz}, 3 \mathrm{H}), 2.6(\mathrm{q}, J=7.5 \mathrm{~Hz}, 2 \mathrm{H}), 3.10(\mathrm{~s}, 3 \mathrm{H}), 7.20(\mathrm{~m}$, $1 \mathrm{H}), 7.70-8.00$ (m, 7H), 10.7 (s, 1H); Mass (CI method): $388.1\left(\mathrm{M}^{+}, 100 \%\right)$; Elemental analysis: Calculated for $\mathrm{C}_{18} \mathrm{H}_{17} \mathrm{~N}_{3} \mathrm{O}_{5} \mathrm{~S}, \mathrm{C} 55.80, \mathrm{H} 4.42, \mathrm{~N} 10.85 \%$; found C 55.76, $\mathrm{H} 4.40$, N $10.89 \%$.

4-O-Benzoyl-1,2-benzothiazine-3-carboxamide-2-methyl$N$-(2-pyridyl)-1,1-dioxide (4c)

mp $185^{\circ} \mathrm{C}$; IR $\left(\mathrm{KBr}, \mathrm{cm}^{-1}\right): 3324(\mathrm{~N}-\mathrm{H}), 1735(\mathrm{C}=\mathrm{O})$, $1685(\mathrm{C}=\mathrm{O}) ;{ }^{1} \mathrm{H}$ NMR $\left(400 \mathrm{MHz}, \mathrm{CDCl}_{3}\right) \delta 3.20(\mathrm{~s}, 3 \mathrm{H})$, 7.20-8.40 (m, 13H), $11.0(\mathrm{~s}, 1 \mathrm{H})$; Mass (CI method): $436\left(\mathrm{M}^{+}, 100 \%\right)$; Elemental analysis: Calculated for $\mathrm{C}_{22} \mathrm{H}_{17} \mathrm{~N}_{3} \mathrm{O}_{5} \mathrm{~S}, \mathrm{C} 60.68, \mathrm{H} 3.93, \mathrm{~N} 9.65 \%$; found C 60.49, H 3.98, N $9.69 \%$.

1,2-Benzothiazine-3-carboxamide-4-O-(2-chlorobenzoyl)2-methyl-N-(2-pyridyl)-1,1-dioxide (4d)

IR $\left(\mathrm{KBr}, \mathrm{cm}^{-1}\right): 3325(\mathrm{~N}-\mathrm{H}), 1732(\mathrm{C}=\mathrm{O}), 1680(\mathrm{C}=\mathrm{O})$; ${ }^{1} \mathrm{H}$ NMR $\left(200 \mathrm{MHz}, \mathrm{CDCl}_{3}\right) \delta 3.21$ (s, 3H), 7.21-7.88 (m, $10 \mathrm{H}), 8.07-8.11(\mathrm{~m}, 2 \mathrm{H}), 11.0(\mathrm{~s}, 1 \mathrm{H})$; Mass (CI method): $470\left(\mathrm{M}^{+}, 100 \%\right)$; Elemental analysis: Calculated for $\mathrm{C}_{22} \mathrm{H}_{16} \mathrm{ClN}_{3} \mathrm{O}_{5} \mathrm{~S}, \mathrm{C} 56.23, \mathrm{H} 3.43, \mathrm{~N}$ 8.94\%; found C 56.41, $\mathrm{H} 3.38, \mathrm{~N} 8.90 \%$. 
1,2-Benzothiazine-3-carboxamide-4-O-(2-methylbenzoyl)2-methyl-N-(2-pyridyl)-1,1-dioxide (4e)

mp $164{ }^{\circ} \mathrm{C}$; IR $\left(\mathrm{KBr}, \mathrm{cm}^{-1}\right): 3327(\mathrm{~N}-\mathrm{H}), 1734(\mathrm{C}=\mathrm{O})$, $1682(\mathrm{C}=\mathrm{O}) ;{ }^{1} \mathrm{H} \mathrm{NMR}\left(400 \mathrm{MHz}, \mathrm{CDCl}_{3}\right) \delta 2.67(\mathrm{~s}, 3 \mathrm{H})$, $3.20(\mathrm{~s}, 3 \mathrm{H}), 7.40(\mathrm{~m}, 3 \mathrm{H}), 7.50(\mathrm{~m}, 1 \mathrm{H}), 7.70(\mathrm{~m}, 3 \mathrm{H})$, $8.00(\mathrm{~d}, J=5.2 \mathrm{~Hz}, 1 \mathrm{H}), 8.10(\mathrm{t}, J=5.4 \mathrm{~Hz}, 1 \mathrm{H}), 8.40$ $(\mathrm{m}, 2 \mathrm{H}), 8.70(\mathrm{~d}, J=1.2 \mathrm{~Hz}, 1 \mathrm{H}), 11.9(\mathrm{~s}, 1 \mathrm{H})$; Mass (CI method): $450\left(\mathrm{M}^{+}, 100 \%\right)$; Elemental analysis: Calculated for $\mathrm{C}_{23} \mathrm{H}_{19} \mathrm{~N}_{3} \mathrm{O}_{5} \mathrm{~S}, \mathrm{C} 61.46, \mathrm{H} 4.26, \mathrm{~N} 9.35 \%$; found C 61.40, H 4.27, N 9.39\%.

1,2-Benzothiazine-3-carboxamide-4-O-(4methoxybenzoyl)-2-methyl-N-(2-pyridyl)-1,1-dioxide (4f)

mp $165^{\circ} \mathrm{C}$; IR $\left(\mathrm{KBr}, \mathrm{cm}^{-1}\right): 3326(\mathrm{~N}-\mathrm{H}), 1736(\mathrm{C}=\mathrm{O})$, $1684(\mathrm{C}=\mathrm{O}) ;{ }^{1} \mathrm{H}$ NMR $\left(400 \mathrm{MHz}, \mathrm{CDCl}_{3}\right) \delta 3.15(\mathrm{~s}, 3 \mathrm{H})$, $3.80(\mathrm{~s}, 3 \mathrm{H}), 7.00(\mathrm{~m}, 3 \mathrm{H}), 7.60-7.70(\mathrm{~m}, 4 \mathrm{H}), 7.90(\mathrm{~m}, 1 \mathrm{H})$, 8.10-8.20 (m, $3 \mathrm{H}), 8.30(\mathrm{~m}, 1 \mathrm{H}), 9.07(\mathrm{~s}, 1 \mathrm{H})$; Mass (CI method): $466\left(\mathrm{M}^{+}, 100 \%\right)$; Elemental analysis: Calculated for $\mathrm{C}_{23} \mathrm{H}_{19} \mathrm{~N}_{3} \mathrm{O}_{6} \mathrm{~S}, \mathrm{C} 59.35, \mathrm{H} 4.11, \mathrm{~N} 9.03 \%$; found C 59.46, $\mathrm{H} 4.28, \mathrm{~N} 8.85 \%$.

\section{1,2-Benzothiazine-3-carboxamide-2-methyl-4-O-(4- nitrobenzoyl)-N-(2-pyridyl)-1,1-dioxide (4g)}

mp $196^{\circ} \mathrm{C}$; IR $\left(\mathrm{KBr}, \mathrm{cm}^{-1}\right): 3323(\mathrm{~N}-\mathrm{H}), 1749(\mathrm{C}=\mathrm{O})$, $1679(\mathrm{C}=\mathrm{O}) ;{ }^{1} \mathrm{H} \mathrm{NMR}\left(400 \mathrm{MHz}, \mathrm{CDCl}_{3}\right) \delta 3.10(\mathrm{~s}, 3 \mathrm{H})$, $7.10(\mathrm{~m}, 1 \mathrm{H}), 7.60-7.80(\mathrm{~m}, 4 \mathrm{H}), 7.90(\mathrm{~d}, J=7.5 \mathrm{~Hz}, 1 \mathrm{H})$, $8.10(\mathrm{~d}, J=4.3 \mathrm{~Hz}, 1 \mathrm{H}), 8.30-8.40(\mathrm{~m}, 5 \mathrm{H}), 9.10(\mathrm{~s}, 1 \mathrm{H})$; Mass (CI method): $481\left(\mathrm{M}^{+}, 100 \%\right)$; Elemental analysis: Calculated for $\mathrm{C}_{22} \mathrm{H}_{16} \mathrm{~N}_{4} \mathrm{O}_{7} \mathrm{~S}, \mathrm{C} 55.00, \mathrm{H} 3.36, \mathrm{~N} 11.66 \%$; found C 55.16, H 3.29, N 11.75\%.

1,2-Benzothiazine-3-carboxamide-4-O-(4methylbenzenesulfonyl)-2-methyl- $N$-(2-pyridyl)-1,1dioxide (5a)

mp $149^{\circ} \mathrm{C}$; IR $\left(\mathrm{KBr}, \mathrm{cm}^{-1}\right): 3325(\mathrm{~N}-\mathrm{H}), 1738(\mathrm{C}=\mathrm{O})$, $1688(\mathrm{C}=\mathrm{O}) ;{ }^{1} \mathrm{H}$ NMR $\left(400 \mathrm{MHz}, \mathrm{CDCl}_{3}\right) \delta 2.30(\mathrm{~s}, 3 \mathrm{H})$, $3.00(\mathrm{~s}, 3 \mathrm{H}), 7.20(\mathrm{~m}, 3 \mathrm{H}), 7.60(\mathrm{~d}, J=8.4 \mathrm{~Hz}, 2 \mathrm{H}), 7.70$ $(\mathrm{m}, 6 \mathrm{H}), 8.40(\mathrm{~d}, J=4.3 \mathrm{~Hz}, 1 \mathrm{H}), 10.9(\mathrm{~s}, 1 \mathrm{H})$; Mass (CI method): $486\left(\mathrm{M}^{+}, 100 \%\right)$; Elemental analysis: Calculated for $\mathrm{C}_{22} \mathrm{H}_{19} \mathrm{~N}_{3} \mathrm{O}_{6} \mathrm{~S}_{2}, \mathrm{C} 54.42, \mathrm{H} 3.94, \mathrm{~N} 8.65 \%$; found $\mathrm{C}$ $54.46, \mathrm{H} 3.98, \mathrm{~N} 8.53 \%$.

4-O-(4-Acetylamino benzenesulfonyl)-1,2-benzothiazine-3carboxamide-2-methyl-N-(2-pyridyl)-1,1-dioxide (5b)

mp $170{ }^{\circ} \mathrm{C} ;{ }^{1} \mathrm{H} \mathrm{NMR}\left(400 \mathrm{MHz}, \mathrm{CDCl}_{3}\right) \delta 2.10(\mathrm{~s}, 3 \mathrm{H})$, $3.0(\mathrm{~s}, 3 \mathrm{H}), 7.10(\mathrm{~m}, 1 \mathrm{H}), 7.20-7.90(\mathrm{~m}, 10 \mathrm{H}), 8.30(\mathrm{~m}, 1 \mathrm{H})$,
10.3 (s, 1H), 10.9 (s, 1H); Mass (CI method): $528\left(\mathrm{M}^{+}\right.$, $100 \%$ ); Elemental analysis: Calculated for $\mathrm{C}_{23} \mathrm{H}_{20} \mathrm{~N}_{4} \mathrm{O}_{7} \mathrm{~S}_{2}$, C 52.26, H 3.81, N 10.60\%; found C 52.40, H 3.88, N $10.35 \%$.

\section{Acknowledgments}

The authors thank Mr. M. N. Raju, the chairman of M.N.R. Educational Trust for his constant encouragement and support. Authors also thank Professor B. C. Ranu, IACS, Kolkata for spectral support and Professor P. Reddanna and Mr. Anil of Hyderabad Central University, India for biological assays.

\section{References}

1. Piroxicam is a well known drug for the treatment of rheumatoid arthritis and osteoarthritis. Its beneficial effects have also been demonstrated in the treatment of musculoskeletal disorder, dysmenorrheal, and postoperative pain. Lazer, E. S.; Miao, C. K.; Cywin, C. L.; Soreck, R.; Wong, H. -C.; Meng, Z.; Potocki, I.; Hoermann, M.; Snow, R. J.; Tschantz, M. A.; Kelly, T. A.; McNeil, D. W.; Coutts, S. J.; Churchill, L.; Graham, A. G.; David, E.; Grob, P. M.; Engel, W.; Meier, H.; Trummlitz, G.; J. Med. Chem. 1997, 40, 980.

2. Hopkins, S. J.; Rabasseda, X.; Drugs Today 1994, 30, 557.

3. Marfat, A. Ether prodrugs of anti-inflammatory oxicams. US Patent 4551452.

4. Farre, A. J.; Colombo, M.; Fort, A.; Gutierrez, B.; Rodriguez, L.; Roser, R.; Methods Find. Exp. Clin. Pharmacol. 1986, 8, 407.

5. Cherie-Ligniere, G.; Montagnani, G.; Alberici, M.; Acerbi, D.; Arzneim.-Forsch./Drug Res. 1987, 37, 560.

6. Prodrugs are pharmacologically inactive derivatives of active drugs. These derivatives are designed to maximize the amount of active drug that reaches its site of action, via manipulation of the physicochemical, biopharmaceutical or pharmacokinetic properties of the parent drug. For excellent reviews, see: Bundgaard, H. Design of prodrugs: bioreversible derivatives for various functional groups and chemical entities. In Design of Prodrugs; Bundgaard, H., Ed., Elsevier: Amsterdam, 1985; Chapter 1, pp 1-92; Bundgaard, H. Novel chemical approaches in prodrug design. Drugs Future 1991, 16, 443; For a recent example of an enol prodrug, see: Burkhart, J. P.; Koehl, J. R.; Mehdi, S.; Durham, S. L.; Janusz, M. J.; Huber, E. W.; Angelastro, M. R.; Sunder, S.; Metz, W. A.; Shum, P. W.; Chen, T.-M.; Bey, P.; Cregge, R. J.; Peet, N. P.; J. Med. Chem. 1995, 38, 223.

7. Burch, R. M.; Wise, W. C.; Halushka, P. V.; J. Pharm. Exp. Ther. 1983, 227, 84; Tsai, R.-S.; Carrupt, P.-A.; El-Tayar, N.; Giroud, Y.; Andrade, P.; Testa, B.; Bree, F.; Tillement, J.-P.; Helv. Chim. Acta 1993, 76, 842. 
8. Andrade, S. M.; Costa, S. M. B.; Prog. Colloid Polym. Sci. 1996, 100, 195.

9. Kim, Y. H.; Cho, D. W.; Kang, S. G.; Yoon, M.; Kim, D.; J. Lumin. 1994, 59, 209.

10. Andrade, S. M.; Costa, S. M. B.; Phys. Chem. Chem. Phys. 1999, 1, 4213.

11. Banerjee, R.; Chakraborty, H.; Sarkar, M.; Biopolymers 2004, 75,355 .

12. Andrade, S. M.; Costa, S. M. B.; Pansu, R.; Photochem. Photobiol. 2000, 71, 405 .

13. Rozou, S.; Voulgari, A.; Antoniadou-Vyza, E.; Eur. J. Pharm. Sci. 2004, 21, 661.

14. Pericherla, S.; Mareddy, J.; D. P., Geetha Rani; Gollapudi, P. V.; Pal, S.; J. Braz. Chem Soc. 2007, 18, 384; Sandhya, P.; Gollapudi, P. V.; Pal, S. "Synthesis of $N$-Alkyl and Acyl Derivatives of Nimesulide" Presented at the National Seminar on Emerging Trends in Synthetic Aspects of Medicinal Chemistry 28 \& 29 October 2005, Warangal, Andhra Pradesh, India. Abstract no P-1; Pal, S.; Bindu, P.; Venna, P. R.; Dubey, P. K.; Lett. Org. Chem. 2007, 4, 292; Pal, S.; Bindu, P.; Venna, P. R.; Dubey, P. K. "Green Synthesis of Naproxen Derivatives via C-C Bond Formation Reactions" Presented at the International Symposium on Current Perspectives in Organic Chemistry, December 7-9, 2006, IACS, Kolkata, India. Abstract No. P-35.

15. Sonntag, N. O. V. Chem. Rev. 1953, 52, 237; Thompson, Q. E.; J. Am. Chem. Soc. 1951, 73, 5841; See also: Trost, B.M.; Chan, D.M.T.; J. Am. Chem. Soc. 1981, 103, 5972.
16. Although single crystal X-ray diffraction is undoubtedly the most powerful and widely used technique for elucidating the structure of organic and metal-organic compounds, an intrinsic limitation of this techniques is the requirement to prepare single crystals of appropriate size and quality, which are not always met for all compounds in the chosen crystal growth conditions and also within a reasonable time scale. In such circumstances, $\mathrm{X}$-ray powder diffraction can be used as an alternative route for structural analysis.

17. For a detailed study and relevant data, please see: Chakraborty, S.; Ghosh, S.; Cheemala, J. M. S.; Jayaselli, J.; Pal, S.; Mukherjee, A. K.; Z Krist 2007, 222, 437; Crystallographic data (excluding structure factors) for compound $\mathbf{4} \mathbf{f}$ have been deposited with the Cambridge Crystallographic Data Centre as supplementary publication numbers CCDC 641048.

18. A typical reaction mixture containing $50 \mathrm{mM}$ Tris buffer, $\mathrm{pH}$ 7.4 and compound was incubated at $37{ }^{\circ} \mathrm{C}$ in water bath for $2 \mathrm{~h}$. The reaction was terminated by cooling it to $5-10{ }^{\circ} \mathrm{C}$ and extracted with chloroform. The organic layers were collected, dried over anhydrous $\mathrm{Na}_{2} \mathrm{SO}_{4}$ and concentrated. The residue was analyzed.

19. Enzyme activity was measured using a chromogenic assay based on oxidation of $N, N, N^{\prime}, N^{\prime}$-tetramethyl-p-phenylenediamine (TMPD) during the reduction of PGG2 to PGH2 according to the procedure reported in the literature, see Copeland, R. A.; Williams, J. M.; Giannaras, J.; Nurnberg, S.; Covington, M.; Pinto, D.; Pick, S.; Trzaskos, J. M.; Proc. Natl. Acad. Sci. USA 1994, 91, 11202. 